\title{
Centres and Peripheries in the Early Second Temple Period
}

\author{
Ed. by Ehud Ben Zvi and Christoph Levin \\ [Zentrum und Peripherie in der frühen Zeit des Zweiten Tempels.]
}

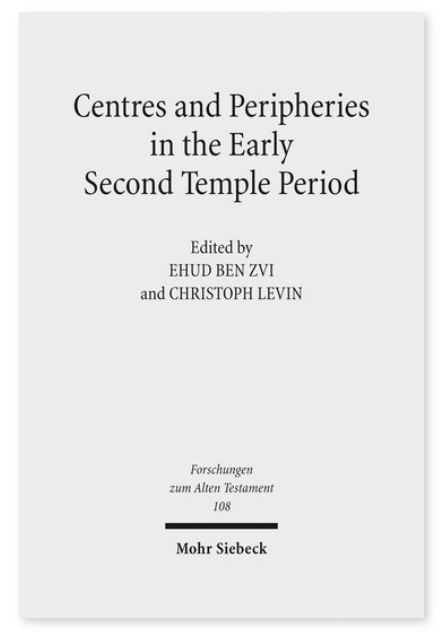

2016. XIV, 469 Seiten. FAT 108

ISBN 978-3-16-155025-6

DOI 10.1628/978-3-16-155025-6

eBook PDF 154,00€

ISBN 978-3-16-154293-0

Leinen $154,00 €$
Veröffentlicht auf Englisch.

Modelle von »Zentrum und Peripherie« haben sich bei der Untersuchung von Systemen bewährt, deren Kräftespiel von einer ungleichen Verteilung von Eigenschaften bestimmt ist. Was können diese Modelle, die eine große Vielfalt aufweisen, in ihren unterschiedlichen Anwendungsbereichen zur Erforschung der frühen Zeit des Zweiten Tempels beitragen? Die in diesem Band versammelten Aufsätze betreffen unter anderem die Rolle Jerusalems und der jüdischen Diaspora, die Bedeutung der Tora, das Verhältnis von Tempel und Königshof, die Beziehung zwischen Jerusalem und dem Garizim, die Zionstradition, die Vorstellung des universalen Herrschaft JHWHs, redaktionsgeschichtliche Fragen, schichtenspezifische Sprachdifferenz und die Bedeutung von Geschlechterrollen.

\section{Inhaltsübersicht}

Ehud Ben Zvi: Introduction - Ehud Ben Zvi: Introductory Centre/Core-Periphery Considerations and the Case of Interplaying of Rigid and Flexible Constructions of Centre and Periphery among the Literati of the Late Persian/Early Hellenistic Period Laurie E. Pearce: Looking for Judeans in Babylonia's Core and Periphery - Bob Becking: Centre, Periphery, and Interference: Notes on the »Passover/Mazzot «-Letter from Elephantine - Sy/vie Honigman: Intercultural Exchanges in the Hellenistic East: The Respective Roles of Temples, Royal Offices, Courts, and Gymnasia - Diana Edelman: Identities within a Central and Peripheral Perspective: The Use of Aramaic in the Hebrew Bible - Francis Landy: Between Centre and Periphery: Space and Gender in the Book of Judges in the Early Second Temple Period - Hermann-Josef Stipp: Jeremiah 24: Deportees, Remainees, Returnees, and the Diaspora - Kåre Berge: Are There Centres and Peripheries in Deuteronomy? - Reinhard Müller: The Altar on Mount Gerizim (Deuteronomy 27:1-8): Centre or Periphery? - Erik Aurelius: Periphery as Provocation? 1 Kings 17 and 2 Kings 5 - Magnar Kartveit: The Temple of Jerusalem as the Centre of Affairs in the Book of Chronicles: Memories of the Past and Contemporary Social Setting - Louis C. Jonker: Being both on the Periphery and in the Centre: The Jerusalem Temple in Late Persian Period Yehud from Postcolonial Perspective - Gary N. Knoppers: What is the Core and What is the Periphery in Ezra-Nehemiah? - Juha Pakkala: Centres and Peripheries in the Ezra Story - Friedhelm Hartenstein: The King on the Throne of God: The Concept of World Dominion in Chronicles and Psalm 2 - Beate Ego: Jerusalem and the Nations: „Centre and Periphery « in the Zion Tradition - Kathrin Liess: Centre and Periphery in Psalm 137 - Christoph Levin: The Edition of the Psalms of Ascents - Ann-Cathrin Fiß: "As far as the east is from the west, so far does he remove our transgressions from us « (Psalm 103:12): Mercy as the Centre of Psalm 103 - Urmas Nõmmik: Qinah Meter: From Genre Periphery to Theological Centre - A Sketch - Peter Juhás: „Centre« and »Periphery« in the Apocalyptic Imagination: The Vision of the Ephah (Zechariah 5:5-11) and the Syriac Apocalypse of Baruch as Case Study

Christoph Levin Geboren 1950; 1998 bis zu seiner Emeritierung 2016 Professor an der Ludwig-Maximilians-Universität München; Mitglied der Akademie der Wissenschaften zu Göttingen und der Finnischen Akademie der Wissenschaften; 201013 Präsident der International Organization for the Study of the Old Testament (IOSOT).

Ehud Ben Zvi Born 1951; Professor (History \& Classics) at the University of Alberta; has served and serves as chair of program units/research programmes at the Society of Biblical Literature and the European Association of Biblical Studies ; founder and general editor of the Journal of Hebrew Scriptures and former president of the Canadian Society of Biblical Studies.

Jetzt bestellen:

https://mohrsiebeck.com/buch/centres-and-peripheries-in-the-early-second-temple-period-9783161550256?no_cache=1 order@mohrsiebeck.com

Telefon: +49 (0)7071-923-17

Telefax: +49 (0)7071-51104 